\title{
The EFFECT OF InSTITUTIONAL Trust ON INTERNET BANKING ACCeptance: Perspectives of South African Banking Retail Customers
}

\author{
Daniel K Maduku \\ Department of Marketing Management, Faculty of Management, University of Johannesburg \\ Accepted: June 2016
}

\begin{abstract}
Transactions carried out in the uncertain and impersonal conditions of the Internet require substantial levels of trust. Obtaining customers' trust is therefore imperative to cultivating and nurturing long-lasting and profitable customer-firm relationships in online environments. Surprisingly however, there is currently a dearth of research on the effects of trust on customers' acceptance of e-commerce in Africa. This paper investigates the effects of the components of institutional trust on perceptions of ease of use and usefulness, as well as attitudes towards use on customers' intentions to use Internet banking services. An integrated research model based on the Technology Acceptance Model (TAM) was built and empirically tested using data obtained from 390 retail banking customers in South Africa. The results show that the proposed model possesses high explanatory capabilities as it could explain 61 per cent of the variance in Internet banking use intentions. The study results further show that situational normality is neither a salient determinant of customers' attitudes towards use of internet banking nor their use intention, whereas structural assurance is. By examining the effects of institutional trust on the TAM's variables, especially in a developing African country, this study does not only provide insights for managers in their efforts to achieve rapid adoption of Internet banking, but also contributes to the literature on the topic.
\end{abstract}

Key words: institutional trust, situational normality, structural assurance, Technology Acceptance Model, Internet banking, South Africa

JEL: 033, M310

\section{Introduction}

The 'Internet of Things' (IoT) has created unprecedented opportunities for businesses of all kinds to interact and create sustainable relationships with their customers (Jara, Parra \& Skarmeta, 2014). Indeed, a wide range of businesses have exploited the opportunities provided by the Internet by making significant investments into the provision of Internet-based services to streamline their processes and improve customers' experience. The objective of these enhancements is to build long-term relationships with customers (Erl, Gee, Chelliah, Kress, Normann, Maier \& Wik, 2014; Fjermestad \& Robertson, 2015). The banking industry is one of the frontrunners when it comes to capitalising on the opportunities provided by the Internet due to the implementation of Internet banking (Martins, Oliveira \& Popovič, 2014; Wang \& RubensteinMontano, 2003). Internet banking has the potential to be one of the most profitable financial services (Lee, 2009; Susanto, Lee, Zo \& Ciganek, 2013). However, the acceptance rate of Internet banking is not as widespread as initially predicted (Lichtenstein \& Williamson, 2006; Maduku, 2014). Low levels of customer trust are widely cited as one of the common barriers to the rapid acceptance of Internet banking (Kim, Ferrin \& Rao, 2009; Susanto et al., 2013; Yousafzai, Foxall $\&$ Pallister, 2010). This is because, although all transactions call for some degree of trust, those that are carried out within the uncertain and impersonal circumstances of the Internet require substantial levels of trust owing to the high level of risk commonly associated with online transactions (McKnight, Choudhury \& Kacmar, 2002).

Owing to the indispensable necessity of trust in online transactions, there has recently been a rise in research into the impact of initial trust on e-commerce adoption (Gao \& Waechter 2015; Li, Jiang \& Wu, 2014; Huang, Ba \& Lu, 2014; Kim \& Park, 2013), as well as building trust online 
(Chang \& Fang, 2013; Wu, Huang \& Hsu, 2014), the impact of trust on online transactions (Bleier \& Eisenbeiss 2015; Yan, Zhang \& Vasilakos, 2014), and determinants of online trust (Beldad, Van der Geest, De Jong \& Steehouder, 2012; Shankar, Urban \& Sultan, 2002; Karimov \& Brengman, 2014; Wang \& Emurian, 2005). In spite of growing research interest in online trust, the majority of these studies have been conducted from Western and Asian perspectives. The obvious disparities between consumers from these continents and those in developing countries, particularly in Africa, raise questions about the applicability of research findings obtained in developed countries to African countries (Huang, Ba \& Lu, 2014; Tan \& Chee, 2005). Indeed, Tan and Chee (2005) emphasise that consumers in different countries and cultures have varied expectations of trust towards online transactions. There is therefore a necessity for research that looks into the dimensions of online trust and how this trust affects consumers' behaviour in online environments in different countries (Cook, Yamagishi, Cheshire, Cooper, Matsuda \& Mashima, 2005; Huang et al., 2014; Tan \& Chee, 2005; Yamagishi \& Yamagishi, 1994).

This study responds to this need by examining how the components of institution-based trust affect South African retail banking customers' perceptions, attitudes and intentions towards the use of Internet banking. The banking population of South Africa is estimated to be 27.4 million. However, only 2.3 million of this population actively engage in Internet banking (FinScope, 2014). A Columinate study (2013) shows that 55 per cent of Internet banking users in South Africa are targets for online fraud, with 19 per cent of this population having been victims of a successful attempt and having suffered some form of financial loss. Trust is therefore a vital issue that banks need to contend with in their efforts to achieve a more widespread and enthusiastic acceptance of Internet banking in South Africa.

This study presents practical imperatives to banks and agencies interested in seeing the rapid adoption of Internet banking. By highlighting the impact of institutional trust on customers' perceptions of usefulness, ease of use, attitudes towards use and subsequent use intentions, banks will be able to map out strategies which will increase consumers' trust, thereby fostering their acceptance of the Internet banking system. This study also makes a contribution to the currently limited body of literature on the effects of consumers' trust on e-commerce acceptance in Africa. It does so by testing an integrated model that examines the chain of effects that the components of institutional trust (situational normality and structural assurance) have on consumers' perceptions of usefulness and ease of use as well as their attitudes and intentions towards Internet banking use.

The remainder of the paper is structured as follows: the succeeding section discusses the theoretical background and presents the research model with its associated hypotheses. The third section presents the research methods used in obtaining data for the study. The fourth section presents the results of the empirical data analysis. The fifth section presents the discussion of the results by highlighting the practical and theoretical contributions of the study. The limitations of the study and suggestions for future research are presented in the final section.

\section{Conceptual model and hypotheses}

\subsection{The technology acceptance model (TAM)}

The TAM was developed to shed light on how users' perceptions of the characteristics of information systems (IS) influence their acceptance of the system (Davis, 1989). The TAM is an adaptation of the Theory of Reasoned Action (Fishbein \& Ajzen, 1975) specifically used to explain an individual's acceptance of IS. The TAM emphasises two important customer beliefs; namely perceived usefulness and perceived ease of use, which are the most crucial factors in explaining an individual's IS acceptance behaviour. Perceived usefulness is defined as the "degree to which an individual believes that using a particular system would enhance his / her job performance" and perceived ease of use is defined as "the degree to which an individual believes that using a particular system would be free from mental effort" (Davis, 1989:320). In line with the TRA, the TAM states that the two beliefs (perceived usefulness and perceived ease of use) 
explain an individual's attitude towards using the system. Attitude towards use consequently influences behavioural intention to use, which eventually determines actual use.

The statistical validity and the robustness of the TAM have been confirmed across a wide range of IS domains and use contexts (Cheung \& Vogel, 2013; Edmunds, Thorpe \& Conole, 2012; Wallace \& Sheetz, 2014). Although features of users' task environment are important factors in IS acceptance (Autry, Grawe, Daugherty \& Richey, 2010; Legris, Ingham \& Collerette, 2003), the TAM apparently ignores these factors. Therefore, the TAM lacks task focus (Dishaw \& Strong, 1999; Suh \& Han, 2003). Given that the Internet banking environment is laden with security risks because it requires customers to provide sensitive information such as account and credit card numbers as well as personal identification numbers, consumers need to trust the banks and Internet banking system to safeguard their interest online. To reiterate, it cannot be overstated that trust is a key issue in the acceptance of Internet banking (Alalwan, Dwivedi, Rana, Lal \& Williams, 2015; $\mathrm{Yu}$, Balaji \& Khong, 2015). In an effort to shore up the TAM's limitation of ignoring the elements of the task environment of technology users, this study integrates the components of institutional trust into the TAM to understand Internet banking acceptance among South African banking retail customers.

\subsection{Trust}

Engaging in commercial activities with suppliers often leaves customers in highly uncertain circumstances that may act as a barrier to their intention to carry out these activities in future (Gefen, 2000; Hart \& Saunders, 1997). Failure to reduce this uncertainty would result in customers' resistance to carrying out trading activities with the suppliers. Once again, trust is seen to be a widely essential factor in attempts to reduce customer uncertainty (Suh \& Han, 2003).

Trust is a concept that may be defined and analysed in an interdisciplinary way. Evidence of this is seen in the plethora of research in a wide range of disciplines including sociology (Strub \& Priest, 1976), social psychology (Lindskold, 1978), economics (Dasgupta, 1988), marketing (Moorman, Zaltman \& Deshpande, 1992) and information technology (Grazioli \& Jarvenpaa, 2000). The multi-disciplinary perspectives on trust have given rise to literally dozens of definitions of the concept. For this study, the definition of trust put forward by Grazioli and Jarvenpaa (2000) has been adopted: trust refers to the "belief that the promise of another can be relied upon and that, in unforeseen circumstances, the other will act in a spirit of goodwill and in a benign fashion toward the trustor" (Grazioli \& Jarvenpaa, 2000:398).

There are different forms of trust, and these feature in relationships that vary both in scope and degree (Paul \& McDaniel, 2004). McKnight, Cummings and Chervany (1998) identify five categories of trust: (1) knowledge-based trust, (2) calculative trust, (3) personality-based trust, (4) institution-based trust, and (5) cognition-based trust. According to Wang and Rubenstein-Montano (2003), knowledge-based trust is directly connected to the knowledge that that the trustor has about the trustee, which enables the former to predict the behaviour of the latter with some degree of precision. The central issue here is that based on information derived from the commercial relationship over time, the trustor is able to understand and predict the actions of the trustee. Calculative trust, which is rooted in economics, emphasises calculations as the basis of trust. Proponents of calculative trust argue that trust arises when the trustor believes that the trustee may perform a beneficial function (on the basis of their estimation of the trustee) (Dasgupta, 1988; Williamson, 1993; Moore, 1999). Personality-based trust develops during childhood when an infant seeks and obtains help from a benevolent caregiver, and this results in a general propensity to trust others (McKnight et al., 1998). Institution-based trust denotes the sense of security that a person develops about a situation owing to the guarantees, safety nets, protective mechanisms and other structures (Shapiro, 1987). Proponents of cognition-based trust posit that trust depends on rapid cognitive cues of first impressions as opposed to personal interactions (Brewer, 1981; Meyerson, Weick \& Kramer, 1996). Although these forms of trust vary, they are related (Meyerson et al., 1996). 
Zucker (1986) emphasises that institutional trust is the most imperative trust-creating mode among impersonal economic environments, a recent example of which would be Internet banking. The absence of institutional trust can hinder consumers from accepting e-commerce (Bhattacherjee, 2002). The focus of this study is to understand the impact of institutional trust on factors of Internet banking acceptance. Literature highlights two aspects of institutional trust beliefs: (1) situational normality, which means trustors are likely to trust because the situation is normal; and (2) structural assurances, which have to do with the likelihood of trust owing to the presence of contextual conditions such as promises, contracts, regulations and guarantees (McKnight et al., 1998; Baier, 1986). In this paper, situational normality and structural assurances were integrated into the Technology Acceptance Model (TAM) to ascertain their impact on perceptions of ease of use and usefulness as well as attitudes towards internet banking and Internet banking use intentions among South African retail banking customers. Figure 1 presents the conceptual model proposed for the study.

Figure 1

Conceptual model

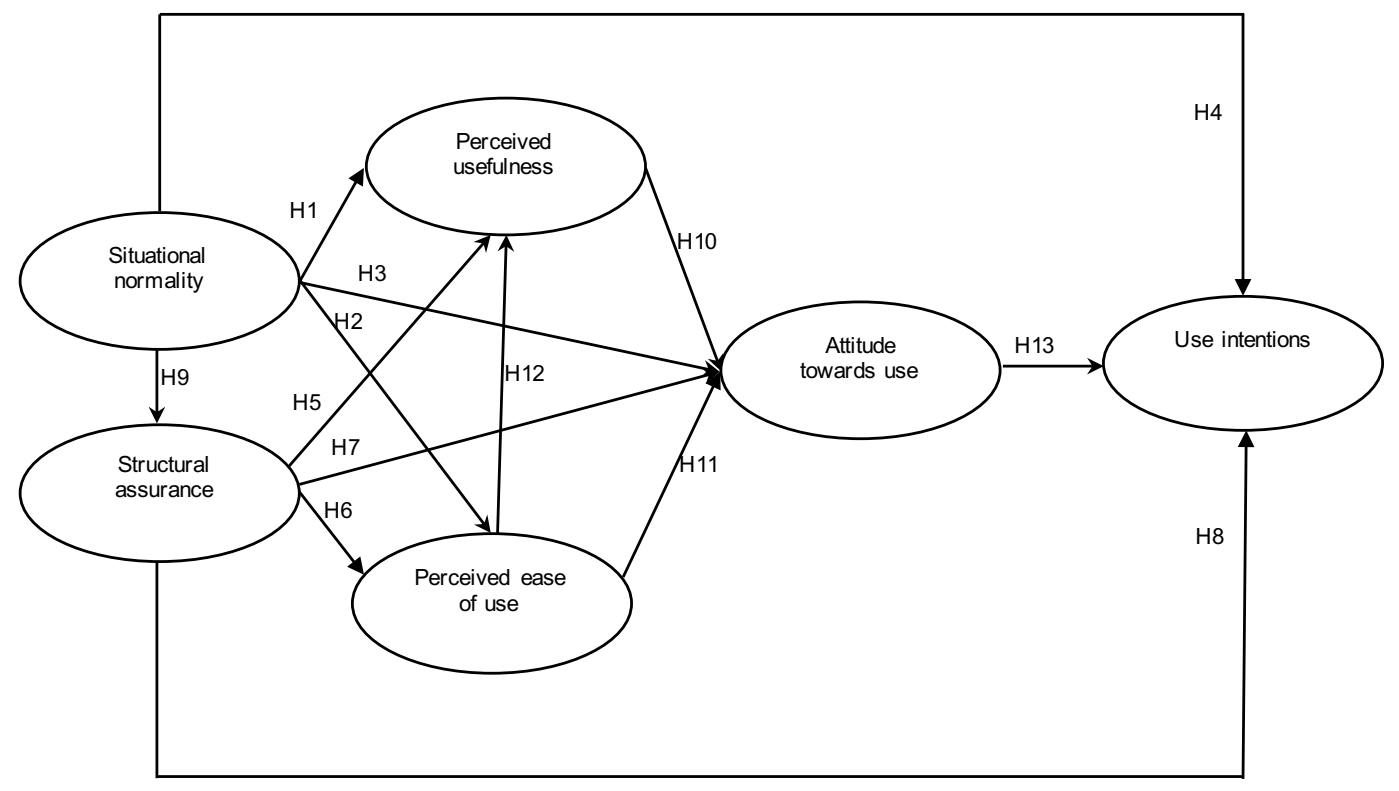

Situational normality denotes the beliefs of customers that the situation in a transaction is normal, beneficial, or favourable to success. Gefen, Karahanna and Straub (2003) emphasise that customers develop higher levels of trust when the interaction between parties is in line with what they would deem to be typical and anticipated. For example, if a bank were to make use of a website that employs a suspicious-looking interface which requires customers to perform an unconventional procedure or provide sensitive information, they would likely hesitate and be less disposed to trust the system. Customers with high levels of situational normality are likely to display high perceptions of regarding Internet banking usefulness and ease of use, and positive attitudes towards Internet banking use. Previous studies have highlighted the association between trust and intention in online environments (Gefen et al., 2003; Hsieh 2015; McKnight \& Chervany, 2001; Pavlou, 2003). In a study of factors explaining the acceptance of electronic medical record exchange systems among Taiwan medical practitioners, Hsieh (2015) observed a positive association between institutional trust and use intention. In line with the foregoing arguments, the following hypotheses are proposed:

H1: Situational normality has a significant, positive effect on perceived usefulness

H2: Situational normality has a significant, positive effect on perceived ease of use 
H3: Situational normality has a significant, positive effect on attitudes towards Internet banking use

H4: Situational normality has a significant, positive effect on Internet banking use intentions

Structural assurance refers to the expectation of success as a result of the presence of contextspecific protection measures, such as legal recourse, regulations and guarantees that are put in place (Gefen, 2000). In the context of Internet banking, structural assurance denotes consumers' perceptions regarding the availability of legal structures that will protect them from the dangers of Internet banking; that is, safeguards that will make customers feel comfortable using the system as well as the availability of Internet security advances (such as encryption) which make it safe for customers to use the platform. Previous studies show that the availability of structural cues including seals of approval, explicit privacy statements, guarantees and affiliation with distinguished companies on transactional online sites boost consumers' trust of the sites and subsequently their inclination to use them (McKnight et al., 2002; Stewart, 1999; Wang, Wang, Lin \& Tang, 2003). Customers who employ Internet banking will perceive the system to be useful and easy to use in the presence of adequate structural assurance cues. Similarly, in the presence of these cues, customers' attitudes towards Internet banking use and its subsequent use intention are expected to be favourable. Gu, Lee and Suh (2009) found a positive relationship between trust and mobile banking use intention among South Koreans. Accordingly, this study proposes the following hypotheses:

H5: Structural assurance has a significant, positive effect on perceived usefulness

H6: Structural assurance has a significant, positive effect on perceived ease of use

H7: Structural assurance has a significant, positive effect on attitude towards Internet banking use

H8: Structural assurance has a significant, positive effect on Internet banking use intentions

Situational normality belief is likely to affect structural assurance. This is because if the Internet banking interface is ordered in such a way that makes it appear likely to facilitate a successful interaction between the consumer and the system, a positive customer perception of the system's structural assurance is likely to be the outcome. Hence the study proposes that:

H9: Situational normality has a significant, positive effect on structural assurance

Prior researchers (Agarwal \& Karahanna, 2000; Gefen et al., 2003; Taylor \& Todd, 1995; Venkatesh, 2000; Venkatesh \& Davis, 2000) have discussed and applied the TAM extensively, and have confirmed its ability to explaining users' IS acceptance behaviour. These researchers have confirmed the TAM's underlying logic that users behave rationally in their decision to use IS; thus the more useful customers find the system to carry out their task and the easier they find the system to use, the more likely they are to develop a positive attitude towards its use and a strong resultant behavioural intention to use the system. In line with this, the following hypotheses are proposed:

H10: Perceived usefulness has a significant, positive effect on attitude towards Internet banking use

H11: Perceived ease of use has a significant, positive effect on attitude towards Internet banking use

H12: Perceived ease of use has a significant, positive effect on perceived usefulness

H13: Attitude towards Internet banking use has a significant, positive effect on use intentions.

\section{Methods}

\subsection{Survey instrument and measurement}

Data gathering for this study was undertaken using a survey. The questionnaire consisted of two sections, the first of which dealt with questions related to demographics and that measured respondents' Internet banking use patterns. The second section of the questionnaire had items measuring the constructs used in the study. 
Measurement items were identified from relevant previous studies and modified to fit Internet banking. The items measuring perceived usefulness (five items), perceived ease of use (four items), situational normality (four items), structural normality (four items), and attitude towards use (five items), were all sourced from Nor (2005) and adapted for this study. The three items measuring use intention were adapted from the study of Al-Somali, Gholami, and Clegg (2009). Each item was measured on a five-point Likert scale with $1=$ strongly disagree, $2=$ disagree, $3=$ neutral, $4=$ agree, and $5=$ strongly agree. The questionnaire was pre-tested with a convenience sample of 20 customers within the targeted population. Each respondent completed a first version of the questionnaire and provided feedback about the time taken to complete it, clarity of instructions, and wording of questions. A number of questions were reworded based on the feedback obtained from the pretesting exercise.

\subsection{Data gathering}

The population for the study was retail banking customers drawn from the four major South African retail banks (ABSA, First National Bank, Nedbank and Standard Bank). These banks were chosen because they represent the largest banking groups in South Africa and each provides Internet banking services to their customers. Owing to the absence of a sampling frame, a nonprobability sampling technique in the form of convenience sampling was used to select the research respondents. Trained research assistants approached customers of the four major banks in designated shopping malls in the Gauteng Province of South Africa during business hours (09h0017h00). Informed consent from the respondents was obtained for all cases, and respondents were briefed about their right to withdraw at any time during or after the study. Respondents were requested to complete a self-administered paper-based questionnaire. A total of 700 questionnaires were distributed; however, only 394 usable responses were obtained, representing an effective response rate of 56 per cent.

\section{Analysis and results}

The statistical analyses involved assessing the descriptive statistics of the sample, measurement items, and internal consistency of the constructs using SPSS version 22. Structural equation modelling making use of AMOS Graphics version 22 was subsequently used to examine the reliability and validity of the measurement model. This was followed by the testing of the structural model to examine its validity by using the various fit indices and the testing of the hypotheses to examine the significant structural paths in the model.

\subsection{Descriptive statistics}

\subsubsection{Sample characteristics}

The descriptive statistics of the sample are presented in Table 1. A total of 201 (51.54 per cent) of the respondents were male, and 189 (48.46 per cent) were female. In terms of the respondents' age, the majority of them ( 39.23 per cent) were between the ages of 18 and 29 years followed by those between the ages of 30 and 39 years ( 30.51 per cent). This showed that over two-thirds of the respondents were below the age of 40 . The results obtained for the monthly income of the respondents indicated that 34.62 per cent of the respondents received a monthly salary of between 0 and $5000 \mathrm{ZAR}$, and 6.67 per cent of the respondents received above 25000 ZAR monthly. Of the 390 respondents surveyed, 229 ( 58.7 per cent) indicated that they used Internet banking, while 161 (41.3 per cent) did not. Users were asked to state the frequency of their Internet banking use. The largest percentage pointed out that they used Internet banking a few times a month; this was followed by those who used the Internet banking once a week (20.52 per cent), a few times a week (19.65 per cent), daily (4.80 per cent), and few times a year (3.06 per cent). 
Table 1

Sample characteristics

\begin{tabular}{|l|l|c|c|}
\hline \multicolumn{2}{|c|}{ Sample characteristics } & Frequency & Percent (\%) \\
\hline \multirow{5}{*}{ Gender } & Male & 201 & 51.54 \\
& Female & 189 & 48.46 \\
\hline & $18-29$ & 153 & 39.23 \\
& $30-39$ & 119 & 30.51 \\
& $40-49$ & 73 & 18.72 \\
& $50-59$ & 25 & 6.41 \\
& $60-69$ & 15 & 3.85 \\
& 70 and older & 5 & 1.28 \\
\hline \multirow{5}{*}{ Monthly income (in ZAR) } & $0-5000$ & 135 & 34.62 \\
& $5001-7500$ & 77 & 19.74 \\
& $7501-10000$ & 52 & 13.33 \\
& $10001-12500$ & 37 & 9.49 \\
& $12501-15000$ & 21 & 5.38 \\
& $15001-17500$ & 16 & 4.10 \\
& $17501-20000$ & 16 & 4.10 \\
& $20001-22500$ & 10 & 2.56 \\
& $25000+$ & 26 & 6.67 \\
\hline \multirow{5}{*}{ Internet banking use } & Yes & 229 & 58.70 \\
& No & 161 & 41.30 \\
\hline \multirow{5}{*}{ Frequency of Internet banking use } & Daily & 11 & 4.80 \\
& A few times a week & 45 & 19.65 \\
& Once a week & 47 & 20.52 \\
& A few times a month & 80 & 34.93 \\
& Once a month & 39 & 17.03 \\
& A few times a year & 7 & 3.06 \\
\hline
\end{tabular}

\subsubsection{Descriptive statistics of constructs}

Table 2 provides the descriptive statistics of the constructs. Inference from the table indicates that all the means exceed the midpoint and the standard deviations are between 0.938 and 1.187, denoting a narrow spread around the mean. The skew values range from -0.290 to -0.911 , and the kurtosis results range from -0.049 to 0.541 . According to Kline (2005) skewness and kurtosis indices should fall within 3 and 10 respectively for data to be considered normal. Following this recommendation, the data for this study were considered as normal for further analysis. Internal consistency of each of the constructs was analysed using Cronbach's alpha (Cronbach, 1951). To achieve internal consistency, the Cronbach alpha values must be 0.7 and above. Results presented in Table 2 indicate that the values for each construct were above the 0.7 threshold, and this suggests that adequate internal consistency was achieved for all the constructs.

Table 2

Descriptive statistics and reliability analysis

\begin{tabular}{|l|c|c|c|c|c|c|}
\hline \multicolumn{1}{|c|}{ Construct } & Item & Mean & SD & Skewness & Kurtosis & $\begin{array}{c}\text { Cronbach's } \\
\text { alpha }\end{array}$ \\
\hline Perceived usefulness & 5 & 3.94 & 0.938 & -0.799 & 0.541 & 0.944 \\
\hline Perceived ease of use & 4 & 3.70 & 1.100 & -0.559 & -0.331 & 0.946 \\
\hline Situational normality & 4 & 3.72 & 0.956 & -0.608 & 0.191 & 0.919 \\
\hline Structural assurance & 4 & 3.32 & 1.027 & -0.290 & -0.398 & 0.928 \\
\hline Attitude towards use & 5 & 3.79 & 1.042 & -0.777 & 0.160 & 0.950 \\
\hline Use intention & 3 & 3.85 & 1.187 & -0.911 & -0.049 & 0.942 \\
\hline
\end{tabular}

\subsection{Measurement model analysis}

The assessment of the measurement model was done in terms of item reliability, convergent validity and discriminant validity. The reliability of the items was first assessed using composited reliability (CR) (Nunnally, 1978). To achieve reliability, CR values should be greater than 0.7 . The results show that the values are above the recommended 0.7 ; thus, construct reliability was established. The reliability of the individual items was also examined through the standardised 
factor loading. A high loading denotes that the shared variance between the construct and its measurement is higher than the error variance (Hair, Black, Babin \& Anderson, 2010). A factor loading greater than 0.7 is deemed as highly reliable, and a factor loading less than 0.5 should be dropped (Hair et al., 2010). From the results presented in Table 3, it can be seen that the factor loadings ranged from 0.712 to 0.972 , providing ample evidence of convergent validity. Average Variance Extracted (AVE) was also used to examine convergent validity of the constructs. The AVE of each construct is shown to be greater than the recommended threshold of 0.5 , with a range of 0.736 to 0.841 , further confirming convergent validity. The estimated correlation between pairs of constructs and their corresponding AVEs were used as the criteria for confirming the discriminant validity of the scales. First, the estimated correlation between pairs of constructs should be less than 0.9 in order to confirm adequate discriminant validity (Bagozzi \& Fornell, 1982). Second, the square root of the AVE of each construct should be greater than its correlation with the others (Fornell \& Larcker, 1981). The estimated correlation between all pairs of constructs was less than 0.9, and the AVE of each was greater than its correlation with the other constructs, indicating that discriminant validity was established.

Table 3

Measurement model analysis

\begin{tabular}{|c|c|c|c|c|}
\hline & Constructs/Items & CR & $\begin{array}{l}\text { Factor } \\
\text { loading }\end{array}$ & AVE \\
\hline Percei & ed usefulness (PU) & 0.942 & & 0.767 \\
\hline PU1 & Internet banking makes it easier to do banking activities & & 0.902 & \\
\hline PU2 & Internet banking enables one to do banking activities more quickly & & 0.923 & \\
\hline PU3 & I think Internet banking enables one to complete banking activities more conveniently & & 0.904 & \\
\hline PU4 & I think Internet banking allows one to manage banking activities more efficiently & & 0.807 & \\
\hline PU5 & I think Internet banking is useful in conducting banking activities & & 0.835 & \\
\hline Percei & ed ease of use (PEU) & 0.947 & & 0.816 \\
\hline PEU1 & I think it is easy to learn how to use Internet banking & & 0.935 & \\
\hline PEU2 & I think it is easy to get Internet banking to do what I want it to do & & 0.922 & \\
\hline PEU3 & I think it is easy to become skilful at using Internet banking & & 0.934 & \\
\hline PEU4 & Overall, I think Internet banking is easy to use & & 0.818 & \\
\hline Situatic & nal normality (SN) & 0.917 & & 0.736 \\
\hline SN1 & $\begin{array}{l}\text { Banks that provide Internet banking services have sufficient expertise to provide the } \\
\text { services }\end{array}$ & & 0.910 & \\
\hline SN2 & Banks that provide Internet banking services have the ability to handle the services & & 0.929 & \\
\hline SN3 & $\begin{array}{l}\text { Banks that provide Internet banking services are ready and willing to assist and help } \\
\text { customers with electronic service issues }\end{array}$ & & 0.819 & \\
\hline SN4 & $\begin{array}{l}\text { Banks that provide Internet banking services act ethically in dealing with electronic } \\
\text { banking customers }\end{array}$ & & 0.712 & \\
\hline Structu & ral assurance (SA) & 0.929 & & 0.765 \\
\hline SA1 & I think Internet banking has enough safeguards to make me feel comfortable using it & & 0.843 & \\
\hline SA2 & $\begin{array}{l}\text { I feel assured that legal structures adequately protect me from problems associated } \\
\text { with using Internet banking services }\end{array}$ & & 0.934 & \\
\hline SA3 & $\begin{array}{l}\text { I feel confident that technological advances (such as encryption) on Internet makes it } \\
\text { safe for me to use Internet banking }\end{array}$ & & 0.860 & \\
\hline SA4 & In general the Internet is a safe environment in which to transact banking activities & & 0.830 & \\
\hline Attitud & towards Internet banking use (ATU) & 0.943 & & 0.770 \\
\hline ATU1 & Using Internet banking is a good idea & & 0.764 & \\
\hline ATU2 & I like the idea of using Internet banking & & 0.848 & \\
\hline ATU3 & Using Internet banking is a pleasant idea & & 0.919 & \\
\hline ATU4 & Using Internet banking is an appealing idea & & 0.943 & \\
\hline ATU5 & Using Internet banking is an exciting idea & & 0.857 & \\
\hline Use int & ention (UI) & 0.940 & & 0.841 \\
\hline UI1 & I intend to start/continue using Internet banking services in the future & & 0.844 & \\
\hline $\mathrm{UI} 2$ & I will use Internet banking services regularly in the future & & 0.972 & \\
\hline UI3 & I will strongly recommend Internet banking for others to use it & & 0.931 & \\
\hline
\end{tabular}


Table 4

Discriminant validity

\begin{tabular}{|l|l|c|c|c|c|c|c|}
\hline \multicolumn{2}{|c|}{} & $\mathbf{1}$ & $\mathbf{2}$ & $\mathbf{3}$ & $\mathbf{4}$ & $\mathbf{5}$ & $\mathbf{6}$ \\
\hline $\mathbf{1}$ & Use intention & $\mathbf{0 . 9 1 7}$ & & & & & \\
\hline $\mathbf{2}$ & Perceived ease of use & 0.645 & $\mathbf{0 . 9 0 4}$ & & & & \\
\hline $\mathbf{3}$ & Situational normality & 0.663 & 0.737 & $\mathbf{0 . 8 5 8}$ & & & \\
\hline $\mathbf{4}$ & Structural assurance & 0.634 & 0.642 & 0.728 & $\mathbf{0 . 8 7 5}$ & & \\
\hline $\mathbf{5}$ & Attitude towards use & 0.773 & 0.714 & 0.728 & 0.739 & $\mathbf{0 . 8 7 8}$ & \\
\hline $\mathbf{6}$ & Perceived usefulness & 0.687 & 0.819 & 0.763 & 0.593 & 0.732 & $\mathbf{0 . 8 7 6}$ \\
\hline
\end{tabular}

Note: the bold numbers in the diagonal row are the square roots of the AVE

\subsection{Structural model analysis}

The evaluation of the theoretical model was achieved with the aid of structural model analysis. The validity of the model was first established by examining its goodness of fit. Subsequently, the hypotheses were examined by analysing the significance and the size of the structural paths, and the percentage of variance explained. The $\chi^{2} / d f$, NFI, TLI, CFI, and RMSEA fit indices were used to assess the goodness of fit. Table 5 presents the goodness of fit values estimated for each fit index and their recommended limits.

Table 5

Structural model goodness-of-fit indices

\begin{tabular}{|l|c|l|c|}
\hline Fit indices & Recommended limit & \multicolumn{1}{|c|}{ Source } & Estimated values \\
\hline $\mathrm{X}^{2} / d f$ & $<5$ & Bentler and Bonett (1980) & 2.561 \\
\hline $\mathrm{NFI}$ & $\geq 0.9$ & Bentler and Bonett (1980) & .995 \\
\hline TLI & $\geq 0.9$ & Bentler (1989); Bentler and Bonett (1980); & .989 \\
\hline CFI & $\geq 0.9$ & Hair et al. (2010); Jöreskog and Sörbom (1986) & .997 \\
\hline RMSEA & $\leq .0 .08$ & Hair et al. (2010); Jöreskog and Sörbom (1986) & .062 \\
\hline
\end{tabular}

As can be seen from Table 5, all of the fit indices satisfy the recommended values and thus exhibit a good fit with the collected data. The results of the structural paths are presented in Figure 2 . The results reveal that situational normality is significantly and positively $(\beta=0.31, p<0.001)$ associated with perceived usefulness, providing support for $\mathrm{H} 1$. A test of $\mathrm{H} 2$ similarly reveals that situational normality has a significant and positive $(\beta=0.24, p<0.001)$ effect on perceived ease of use. Therefore, $\mathrm{H} 2$ is supported. The results show that situational normality is neither significantly related to customers' attitudes towards Internet banking use nor their intention to the use the service; hence $\mathrm{H} 3$ and $\mathrm{H} 4$ are not supported.

The results also show that structural assurance has an insignificant effect on perceived usefulness, therefore support for H5 was not obtained. However, the study showed that the association between structural assurance and perceived ease of use is significant and positive $(\beta=0.47, p<0.001)$, therefore H6 is supported. Similarly, structural assurance has a significant and positive $(\beta=0.38, p<$ 0.001) effect on consumers' attitudes towards Internet banking use, thus providing support for H7. Support for $\mathrm{H} 8$ was also obtained as the results show that structural normality is significant and positively $(\beta=0.30, p<0.001)$ associated with Internet banking use intention. The results further demonstrate that situational normality is significantly and positively $(\beta=0.93, p<0.001)$ associated with structural assurance, hence H9 is supported. A test of H10 reveals that perceived usefulness is positively and significantly related to attitude towards Internet banking use $(\beta=0.31, p<0.001)$. Therefore, H10 is supported. Similarly, as perceived ease of use has a significant and positive $(\beta=0.15, p<0.01)$ effect on attitudes towards Internet banking use, H11 is supported. The results of the analysis also provide support for $\mathrm{H} 12$ that perceived ease of use has a significant and a positive $(\beta=0.56, p<0.001)$ effect on perceived usefulness. Finally, the results show that customers' attitudes towards Internet banking use have a significant and positive $(\beta=0.53, p<0.001)$ effect on their Internet banking use intentions. This therefore provides support for $\mathrm{H} 13$. 
Figure 2

Results of the structural equation model

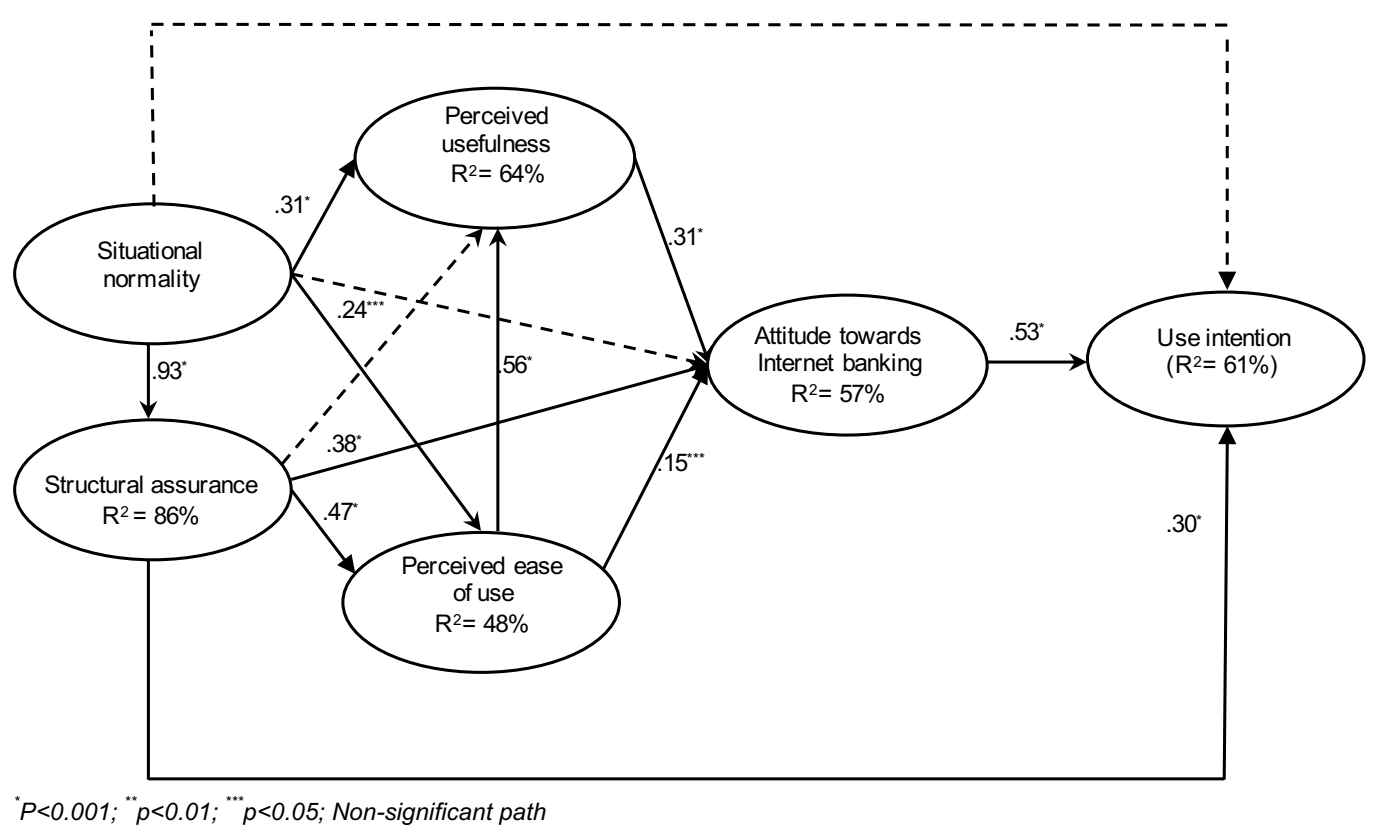

Situational normality and structural assurance jointly explain 48 per cent of the variance in perceived ease of use. Situational normality and perceived ease of use jointly explain close to two thirds (64 per cent) of the variance in perceived usefulness. Perceived usefulness, perceived ease of use and structural assurance collectively explain 57 per cent of the variance in attitude towards Internet banking use. Situational normality accounts for 86 per cent of the variance in structural assurance. Finally, attitude towards Internet banking use and structural assurance explain 61 per cent of the variance in Internet banking use intentions.

\section{Discussion}

\subsection{Managerial implications}

The purpose of this study was to ascertain the effects of components of institutional trust: namely situational normality and structural assurance, on perceived usefulness, perceived ease of use, attitudes towards use and Internet banking use intentions among South African retail banking customers. The findings of this study generally support the hypotheses from the research model and prior empirical research. Overall, the model demonstrates a good fit with the data. Moreover, 10 of the 13 hypotheses are supported. This demonstrates that the research model has good explanatory power in meeting the purpose of the research.

The study shows that situational normality denoting customers' trust of banks offering Internet banking services significantly influences their perception of the usefulness of the service as well as its ease of use. This implies that customers will not perceive Internet banking services as useful and easy to use if their trust in the banks which offer the service is low. Therefore, building customers' trust in the financial institutions offering Internet banking services must be a fundamental element of any strategy aimed at increasing their perception of usefulness and ease of use. In this regard, customer relationship management is widely cited (Eid, 2013; Oppenheim \& Felbur, 2014; Thaidigsmann, 2006) as an effective strategy that banks can use to increase customers' trust in their institutions. Therefore, South African banks and other banks operating in similar economic contexts should take their relationship marketing efforts seriously if they are to succeed in building their 
customers' trust in their institutions. Increased trust will correspond with an increase in customers' perceptions of the usefulness of Internet banking as well as the ease of using the system.

Structural assurance is not significantly related to perceived usefulness. This implies that customers' evaluation of the security and protection systems over the Internet banking system does not contribute to their perception of the system's usefulness. Nevertheless, the study found that structural assurance plays a role in their perceptions of the system's ease of use. Therefore, the implementation of heightened security and protection measures over Internet banking will improve customers' perceptions of ease of using the system. The results further reveal that structural assurance plays a key role in determining customers' attitudes towards Internet banking use as well as their future use intentions. This finding is consistent with that of $\mathrm{Gu}$ et al. (2009), who found a significant positive association between trust and behavioural intention towards mobile banking use among South Korean retail banking customers. To build a positive attitude towards Internet banking, banks must endeavour to implement state-of-the art security and safety measures such as encryption and Internet communication protocols that assure customers of their safety in their Internet banking platform. The communication of these key security and safety features of the system to customers must be central to the marketing strategy in order to facilitate a rapid uptake of Internet banking services among retail banking customers. Once banks succeed in developing a positive attitude towards Internet banking among their customers, they will ultimately succeed in fostering a positive customer intention to start or continue using the system.

The study also found that situational normality has a significant effect on structural normality. In fact, a very significant variance ( 86 per cent) in structural assurance is explained by situational normality. Considering that structural normality plays a noteworthy role in influencing customers' perceptions of ease of use, attitudes towards use and use intention, banks' efforts towards improving their level of structural assurance are paramount in achieving a more rapid acceptance of Internet banking. The findings of this study suggest banks will succeed in improving their level of structural assurance by investing significantly in improving their structural normality.

\subsection{Theoretical implications}

The study makes a number of contributions to existing literature. First, it employed an integrated model that incorporated the components of institutional trust into the TAM to study Internet banking acceptance in a developing country. The integrated model used in this study exhibited high explanatory power as it clarified 61 per cent of the variance in Internet banking use intentions. Although the TAM has repeatedly been demonstrated to be a parsimonious model, empirical testing indicates that the TAM's variables consistently explain 40 per cent of the variance in users' intention to adopt information systems (Autry et al., 2010). This study contributes to the literature by extending the TAM with the components of institutional trust in order to provide stronger explanatory power for Internet banking acceptance.

Secondly, this study empirically tested the effects of situational normality and structural assurance on perceptions of usefulness, ease of use, attitudes towards use and use intention. While situational normality is identified as an important factor for explaining both perceived ease of use and perceived usefulness, structural normality impacts only perceived ease of use and not perceived usefulness. Although there is a considerable body of research on perceived usefulness and perceived ease of use, limited work has been done to ascertain the determinants of these two important drivers with regard to IS acceptance (Susanto \& Aljoza, 2015; Venkatesh, 2000; Scherer, Siddiq \& Teo, 2015). By explaining the effects of situational normality and structural assurance on perceived usefulness and perceived ease of use, this study did not only provide insights into strategies that should be implemented to achieve favourable perceptions of Internet banking acceptance, but it also contributed to enhancing our understanding of the components of institutional trust as determinants of perceptions of usefulness and ease of use.

Thirdly, while previous studies (Guritno \& Siringoringo, 2013; Ozok, Wu, Garrido, Pronovost \& Gurses, 2014; Susanto \& Aljoza, 2015) have highlighted perceived usefulness as the strongest 
predictor of attitude towards use, this study has identified structural assurance as the strongest predictor of consumers' attitudes towards Internet banking. This finding gives researchers and managers an expanded understanding regarding the strength of the factors influencing consumers' attitudes towards Internet banking services.

Finally, although situational normality is an important determinant of customers' perceptions of usefulness and ease of use, it is neither important to their attitude towards Internet banking use or their use intention. This finding is inconsistent with previous studies (Gefen et al., 2003; Hsieh, 2015; Pavlou, 2003) which have found a significant association between trust and intention in online environments. However, these previous studies were based on samples drawn from developed countries. Therefore, this new finding based on a sample drawn from a developing country is important in deepening our understanding of the role of situational normality in Internet banking acceptance in the context of a developing country such as South Africa.

\section{Limitations}

Even though this study yielded useful results that could potentially further our understanding of the drivers of Internet banking acceptance in a developing African country, a number of limitations require consideration. First, the scope of this study was constrained to Internet banking users. Therefore the generalisation of the findings and implications for other technology domains should be treated with caution. Future studies that attempt to replicate the model to understand the acceptance of different technologies could produce different results. Secondly, data for this study were obtained from Gauteng - an urban province of South Africa. The results may have been different if this study were undertaken in a rural area in South Africa. Thirdly, the study stopped short of examining actual behaviour although empirical evidence suggests that use intention has a significant effect on actual behaviour (Ajzen, 1991; Davis, 1989; Venkatesh et al., 2003). Lastly, the use of convenience sampling technique in this study has implications for the generalisability of the study's findings. Future research may consider accumulating empirical evidence and data obtained from probability samples to address the shortcomings of this study.

\section{References}

AGARWAL, R. \& KARAHANNA, E. 2000. Time flies when you're having fun: Cognitive absorption and beliefs about information technology usage. MIS Quarterly, 24(4):665-694.

AJZEN, I. 1991. The theory of planned behavior. Organizational Behavior and Human Decision Processes, 50(2):179-211.

ALALWAN, A.A., DWIVEDI, Y.K., RANA, N.P., LAL, B. \& WILLIAMS, M.D. 2015. Consumer adoption of Internet banking in Jordan: Examining the role of hedonic motivation, habit, self-efficacy and trust. Journal of Financial Services Marketing, 20(2):145-157.

AL-SOMALI, S.A., GHOLAMI, R. \& CLEGG, B. 2009. An investigation into the acceptance of online banking in Saudi Arabia. Technovation, 29:130-141.

AUTRY, C.W, GRAWE, S.J., DAUGHERTY, P.J. \& RICHEY, R.G. 2010. The effects of technological turbulence and breadth on supply chain technology acceptance and adoption. Journal of Operations Management, 28(6):522-536.

BAGOZZI, R.P. \& FORNELL, C. 1982. Theoretical concepts, measurements, and meaning. Published in C. Fornell (ed.) A second generation of multivariate analysis, (pp.5-23). New York: Praeger.

BAIER, A. 1986. Trust and antitrust. Ethics, 96(2):231-260.

BELDAD, A., VAN DER GEEST, T., DE JONG, M. \& STEEHOUDER, M. 2012. A cue or two and I'll trust you: Determinants of trust in government organizations in terms of their processing and usage of citizens' personal information disclosed online. Government Information Quarterly, 29(1):41-49.

BENTLER, P.M. 1989. EQS Structural equations program manual. Los Angeles: BMDP Statistical Software. 
BENTLER, P.M. \& BONETT, D.G. 1980. Significance tests and goodness of fit in the analysis of covariance structures. Psychological Bulletin, 88(3):588-606.

BHATTACHERJEE, A. 2002. Individual trust in online firms: Scale development and initial test. Journal of Management Information Systems, 19(1):211-241.

BLEIER, A. \& EISENBEISS, M. 2015. The importance of trust for personalized online advertising. Journal of Retailing, 91(3):390-409.

BREWER, M.B. 1981. Ethnocentrism and its role in interpersonal trust. In MB Brewer, and BE Collins (eds.) Scientific inquiry and the social sciences, (pp.214-231) San Francisco: Jossey-Bass.

CHANG, Y.S. \& FANG, S.R. 2013. Antecedents and distinctions between online trust and distrust: Predicting high-and low-risk internet behaviors. Journal of Electronic Commerce Research, 14(2):149-166.

CHEUNG, R. \& VOGEL, D. 2013. Predicting user acceptance of collaborative technologies: An extension of the technology acceptance model for e-learning. Computers \& Education, 63:160-175.

COLUMINATE. 2013. Internet banking satisfaction. http://www.columinate.com/internet-bankingsiteisfaction-2013 [accessed June 2015].

COOK, K.S., YAMAGISHI, T., CHESHIRE, C., COOPER, R., MATSUDA, M. \& MASHIMA, R. 2005. Trust building via risk taking: A cross-societal experiment. Social Psychology Quarterly, 68(2):121-142. CRONBACH, L.J. 1951. Coefficient alpha and the internal structure of tests. Psychometrika, 16(3):297-334. DASGUPTA, P. 1988. Trust as a commodity. In D. Gambetta (ed.) Trust: Making and breaking cooperative relations, (pp.49-72). London: Blackwell.

DAVIS, F.D. 1989. Perceived usefulness, perceived ease of use and user acceptance of information technology. MIS Quarterly, 13(3):319-340.

DISHAW, M.T. \& STRONG, D.M. 1999. Extending the technology acceptance model with task-technology fit constructs. Information \& management, 36(1):9-21.

EDMUNDS, R, THORPE, M, \& CONOLE, G. 2012. Student attitudes towards and use of ICT in course study, work and social activity: A technology acceptance model approach. British Journal of Educational Technology, 43(1):71-84.

EID, R. 2013. Managing customers' trust, satisfaction, and loyalty through information communication technologies. Hershey, PA: IGI Global.

FJERMESTAD, J. \& ROBERTSON, N.C. 2015. Electronic customer relationship management. London: Routledge.

ERL, T., GEE, C., CHELLIAH, P.R., KRESS, J., NORMANN, H., MAIER, B. \& WIK, P. 2014. Next generation SOA: A concise introduction to service technology \& service-orientation. New York: Pearson Education.

FISHBEIN, M. \& AJZEN, I. 1975. Belief, attitude, intention, and behavior: An introduction to theory and research, Reading, MA: Addison-Wesley.

FINSCOPE, SA. 2014. Consumer survey. http://www.banking.org.za/docs/default-source/financialinclusion/finscope/finscope-sa-2014.pdf?sfvrsn=12 [accessed December 2015].

FORNELL, C. \& LARCKER, D. 1981. Structural equation models with unobservable variables and measurement error. Journal of Marketing Research, 18(1):39-50.

GAO, L. \& WAECHTER, K.A. 2015. Examining the role of initial trust in user adoption of mobile payment services: An empirical investigation. Information Systems Frontiers, 1-24.

GEFEN, D. 2000. E-commerce: The role of familiarity and trust. Omega, 28(6):725-737.

GEFEN, D., KARAHANNA, E. \& STRAUB, D.W. 2003. Trust and TAM in online shopping: An integrated model. MIS quarterly, 27(1):51-90.

GRAZIOLI, S. \& JARVENPAA, S.L. 2000. Perils of Internet fraud: An empirical investigation of deception and trust with experienced Internet. IEEE Transactions on Systems, Man, and Cybernetics-Part A: Systems and Humans, 30(4):395-410.

GU, J.C., LEE, S.C. \& SUH, Y.H. 2009. Determinants of behavioral intention to mobile banking. Expert Systems with Applications, 36(9):11605-11616.

GURITNO, S. \& SIRINGORINGO, H. 2013. Perceived usefulness, ease of use, and attitude towards online shopping usefulness towards online airline ticket purchase. Procedia-Social and Behavioral Sciences, 81:212-216. 
HAIR, J.F. Jr., BLACK, W.C., BABIN, B.J. \& ANDERSON, R.E. 2010. Multivariate data analysis $\left(7^{\text {th }}\right.$ ed.) Englewood Cliffs, NJ: Prentice Hall.

HART, P. \& SAUNDERS, C. 1997. Power and trust: Critical factors in the adoption and use of electronic data interchange, Organization Science, 8(1):23-42.

HSIEH, P.J. 2015. Physicians' acceptance of electronic medical records exchange: An extension of the decomposed TPB model with institutional trust and perceived risk. International Journal of Medical Informatics, 84(1):1-14.

HUANG, L., BA, S. \& LU, X. 2014. Building online trust in a culture of confucianism? The impact of process flexibility and perceived control. ACM Transactions on Management Information Systems (TMIS), 5(1):1-23, 2014.

JARA, A.J., PARRA, M.C. \& SKARMETA, A.F. 2014. Participative marketing: Extending social media marketing through the identification and interaction capabilities from the Internet of things. Personal and Ubiquitous Computing, 18(4):997-1011.

JÖRESKOG, K.G. \& SÖRBOM, D. 1986. LISREL VI: Analysis of linear structural relationships by maximum likelihood, instrumental variables, and least squares methods. New York: Scientific Software. KARIMOV, F.P. \& BRENGMAN, M. 2014. An examination of trust assurances adopted by top internet retailers: Unveiling some critical determinants. Electronic Commerce Research, 14(4):459-496.

KIM, D.J., FERRIN, D.L. \& RAO, H.R. 2009. Trust and satisfaction, two stepping stones for successful ecommerce relationships: A longitudinal exploration. Information Systems Research, 20(2):237-57.

KIM, S. \& PARK, H. 2013. Effects of various characteristics of social commerce (s-commerce) on consumers' trust and trust performance. International Journal of Information Management, 33(2):318-332. KLINE, T.J. 2005. Psychological testing: A practical approach to design and evaluation. Thousand Oaks: Sage Publications.

LEE, M.C. 2009. Factors influencing the adoption of internet banking: An integration of TAM and TPB with perceived risk and perceived benefit. Electronic Commerce Research and Applications, 8(3):130-141.

LEGRIS, P., INGHAM, J., \& COLLERETTE, P. 2003. Why do people use information technology? A critical review of the technology acceptance model. Information \& Management, 40(3):191-204.

LI, H., JIANG, J. \& WU, M. 2014. The effects of trust assurances on consumers' initial online trust: A twostage decision-making process perspective. International Journal of Information Management, 34(3):395405.

LICHTENSTEIN, S. \& WILLIAMSON, K. 2006. Understanding consumer acceptance of Internet banking: An interpretive study in the Australian banking context. Journal of Electronic Commerce Research, 7(2): 50-66.

LINDSKOLD, S. 1978. Trust development, the GRIT proposal, and the effects of conciliatory acts on conflict and cooperation. Psychological Bulletin, 85(4):772-793.

MADUKU, D.K. 2014. Predicting retail banking customers' attitude towards Internet banking services in South Africa. Southern African Business Review, 17(3):76-100.

MARTINS, C., OLIVEIRA, T. \& POPOVIČ, A. 2014. Understanding the Internet banking adoption: A unified theory of acceptance and use of technology and perceived risk application. International Journal of Information Management, 34(1):1-13.

McKNIGHT, D.H. \& CHERVANY, N.L. 2001. Conceptualizing trust: A typology and e-commerce customer relationships model. In System Sciences, 2001. Proceedings of the 34th Annual Hawaii International Conference on (pp. 10-pp). IEEE.

McKNIGHT, D.H., CHOUDHURY, V. \& KACMAR, C. 2002. Developing and validating trust measures for e-commerce: An integrative typology, Information Systems Research, 13:334-359.

McKNIGHT, D.H., CUMMINGS, L.L. \& CHERVANY, N.L. 1998. Initial trust formation in new organizational relationships. Academy of Management Review, 23(3):473-490.

MEYERSON, D., WEICK, K.E. \& KRAMER, R.M. 1996. Swift trust and temporary groups. Published in R.M. Kramer \& T.R. Tyler (eds.) Trust in organizations: Frontiers of theory and research, (pp.166-195). Thousand Oaks: Sage Publications.

MOORE, M. 1999. Truth, trust and market transactions: What do we know? The Journal of Development Studies, 36(1):74-88. 
MOORMAN, C., ZALTMAN, G. \& DESHPANDE, R. 1992. Relationships between providers and users of market research: The dynamics of trust within and between organizations. Journal of Marketing Research, 29(3):314-328.

NUNNALLY, J.C. 1978. Psychometric theory (2nd ed.) New York: McGraw-Hill.

NOR, K.M. 2005. An empirical study of internet banking acceptance in Malaysia: An extended decomposed theory of planned behavior. An unpublished doctoral thesis. Illinois: Southern Illinois University.

OPPENHEIM, B.W. \& FELBUR, M. 2014. Lean for banks: Improving quality, productivity, and morale in financial offices. Boca Raton: CRC Press.

OZOK, A.A., WU, H., GARRIDO, M., PRONOVOST, P.J. \& GURSES, A.P. 2014. Usability and perceived usefulness of personal health records for preventive health care: A case study focusing on patients' and primary care providers' perspectives. Applied Ergonomics, 45(3):613-628.

PAUL, D.L. \& McDANIEL, R.R. Jr. 2004. A field study of the effect of interpersonal trust on virtual collaborative relationship performance. MIS Quarterly, 28(2):183-227.

PAVLOU, A.P. 2003. Consumer acceptance of electronic commerce: Integrating trust and risk with the technology acceptance model. International Journal of Electronic Commerce, 7(3):69-103.

SCHERER, R., SIDDIQ, F. \& TEO, T. 2015. Becoming more specific: Measuring and modeling teachers' perceived usefulness of ICT in the context of teaching and learning. Computers \& Education, 88:202-214.

SHANKAR, V., URBAN, G.L. \& SULTAN, F. 2002. Online trust: A stakeholder perspective, concepts, implications, and future directions. The Journal of Strategic Information Systems, 11(3):325-344.

SHAPIRO, S.P. 1987. The social control of impersonal trust. American Journal of Sociology, 93(3):623-658. STEWART, K.J. 1999. Transference as a means of building trust in world wide web sites. In Proceedings of the 20th international conference on Information Systems (pp. 459-464). Association for Information Systems.

STRUB, P.J. \& PRIEST, T.B. 1976. Two patterns of establishing trust: The marijuana user. Sociological Focus, 9(4):399-411.

SUH, B. \& HAN, I. 2003. Effect of trust on customer acceptance of Internet banking. Electronic Commerce Research and Applications, 1(3):247-263.

SUSANTO, A., LEE, H., ZO, H. \& CIGANEK, A.P. 2013. User acceptance of Internet banking in Indonesia: Initial trust formation. Information Development, 29(4):309-322.

SUSANTO, T.D. \& ALJOZA, M. 2015. Individual acceptance of e-Government services in a developing country: Dimensions of perceived usefulness and perceived ease of use and the importance of trust and social influence. Procedia Computer Science, 72:622-629.

TAN, H.H. \& CHEE, D. 2005. Understanding interpersonal trust in a Confucian-influenced society: An exploratory study. International Journal of Cross Cultural Management, 5:197-212.

TAYLOR, S. \& TODD, P.A. 1995. Understanding information technology usage: A test of competing models. Information Systems Research, 6(2):144-176.

THAIDIGSMANN, U. 2006. Increasing competitions and changing customer behaviour in the German financial services sector: An analysis of market trends and their consequences for the business model of cooperative banks. Hamburg: Diplom.de.

VENKATESH, V. 2000. Determinants of perceived ease of use: Integrating control, intrinsic motivation, and emotion into the technology acceptance model. Information Systems Research, 11(4):342-365.

VENKATESH, V. \& DAVIS, F.D. 2000. A theoretical extension of the technology acceptance model: Four longitudinal field studies. Management Science, 46(2):186-204.

VENKATESH, V., MORRIS, M.G., DAVIS, G.B. \& DAVIS, F.D. 2003. User acceptance of information technology: Toward a unified view. MIS Quarterly, 27(3):425-478

WALLACE, L.G. \& SHEETZ, S.D. 2014. The adoption of software measures: A technology acceptance model (TAM) perspective. Information \& Management, 51(2):249-259.

WANG, R. \& RUBENSTEIN-MONTANO, B. 2003. The value of trust in knowledge sharing. Published in E. Coakes (ed.) Knowledge management: Current issues and challenges. London: Idea Group.

WANG, Y.D. \& EMURIAN, H.H. 2005. An overview of online trust: Concepts, elements, and implications. Computers in Human Behavior, 21(1):105-125. 
WANG, Y.S., WANG, Y.M., LIN, H.H. \& TANG, T.I. 2003. Determinants of user acceptance of internet banking: An empirical study. International Journal of Service Industry Management, 14(5):501-519.

WILLIAMSON, O.E. 1993. Calculativeness, trust, and economic organization. The Journal of Law \& Economics, 36(1):453-486.

WU, C.C., HUANG, Y. \& HSU, C.L. 2014. Benevolence trust: A key determinant of user continuance use of online social networks. Information Systems and e-Business Management, 12(2):189-211.

YAMAGISHI, T. \& YAMAGISHI, M. 1994. Trust and commitment in the United States and Japan. Motivation and Emotion, 18(2):129-166.

YAN, Z., ZHANG, P. \& VASILAKOS, A.V. 2014. A survey on trust management for Internet of Things. Journal of Network and Computer Applications, 42:120-134.

YOUSAFZAI, S.Y., FOXALL, G.R. \& PALLISTER, J.G. 2010. Explaining internet banking behavior: Theory of reasoned action, theory of planned behavior, or technology acceptance model? Journal of Applied Social Psychology, 40(5):1172-1202.

YU, P.L., BALAJI, M.S. \& KHONG, K.W. 2015. Building trust in internet banking: A trustworthiness perspective. Industrial Management \& Data Systems, 115(2), 235-252.

ZUCKER, L.G. 1986. Production of trust: Institutional sources of economic structure, 1840-1920. Research in Organizational Behaviour, 8:53-111. 